\title{
LIBERTY AS THE IMPOSSIBLE, THE LANGUAGE OF SILENCE: IN REREADING KIM SUYǑNG'S WORKS IN 1960s
}

\author{
Seoyoon CHOI \\ Yonsei University \\ Department of Korean \\ 50 Yonsei-ro, Seodaemun-gu, SEOUL, 03722 \\ South Korea \\ 20010210@hanmail.net
}

\begin{abstract}
This article examines several works written by Kim Suyǒng in the 1960s with a focus on negation as the poetic method in accordance with revolution. He lived through a late colonial period, the Korean War, the April Revolution, and Park Chung Hee's regime and he was keenly aware Koreans had not spoken of liberty as the invention of modernity in our mother tongue throughout our history. He dedicated all his poems to demonstrating why liberty was impossible to be spoken in Korean. In the course of his writing, his authentic poetic language developed into silence as a martyr, the language of death and love. In so doing, he could "live liberty" through his poetry in accordance with his conscience in the authoritarian society.
\end{abstract}

Key words: Kim Suyǒng, liberty, negation, revolution, self-directed violence, death, silence, love 
불가능한 자유, 침묵의 언어: 1960 년대 김수영의 텍스트 다시 읽기

논문초록: 김수영은 ‘자유'의 시인이다. 그에게 근대의 산물인 자유는 한국인들이 모국어로서 발화하지 못한 것이었다. 1960 년대 한국에는 박정희 정권이 집권했다. 군사 독재 정권 하에서 자유에 대한 발언은 억압당했는데, 김수영은 그러한 사태를 '불가능'으로 접수했다. ‘불가능'으로 존재하는 자유를 시로써 발화하는 것은 혁명의 수행을 의미한다. 그는 시작 과정에서 혁명을 부정의 문법으로 실천했고, 그것은 시에서 화자의 자기 폭력으로 나타난다. 그러한 시적 방법은 화자의 죽음으로 메지 나며, 이 때 침묵이 발화된다. '침묵'은 자유를 시로써 말할 수 있는, 그의 '양심'에 근거한 독특한 언어이다. 침묵은 그가 스스로를 끝까지, 무한히 부정함으로써 다른 이를 위해 자유를 상상할 수 있게 했던 ‘사랑의 언어’이다.

주제어: 김수영, 자유, 부정, 혁명, 자기 폭력, 죽음, 침묵, 사랑

\section{WOLNOŚĆ JAKO NIEMOŻNOŚĆ, JEZZYK MILCZENIA: PONOWNIE CZYTAJĄC POEZJĘ AUTORSTWA KIM SUYǑNG}

Streszczenie: W tym artykule rozważa się kilka prac napisanych przez Kim Suyǒng w latach sześćdziesiątych, w których występuje negacja jako metoda poetycka zgodna $\mathrm{z}$ trendem rewolucyjnym. Autor przeżył późny okres kolonialny, wojnę koreańską, kwietniową rewolucję i reżim Parku Chung Hee'a, i był w pełni świadomy, że Koreańczycy nie mówili o wolności jako w swoim języku ojczystym. Swoje wszystkie wiersze poświęcił uświadomieniu ludziom, dlaczego o wolności nie można mówić po koreańsku. W toku pracy twórczej ukształtował się jego prawdziwy język poetycki stanowiący pomnik milczenia męczennika, język śmierci i miłości. Dzięki temu to mógł „żyć wolnością" tworząc poezję zgodnie ze swoim sumieniem jednocześnie żyjąc w społeczeństwie autorytarnym.

Słowa klucze: Kim Suyǒng, poezja koreańska, wolność, metody poetyckie

\section{Preface}

Before embarking upon an analysis of the work of Kim Suyǒng, we will briefly examine the main features of his poetry. First, the theme of his poetry is liberty. Since Kim Hyǒn, one of the foremost Korean literary critics, proposed this in 1974 in "Liberty and Dream", this has not changed. He said that Kim Suyǒng "cried for liberty"(Kim, 13). 64 
Kim Suyǒng addressed, "poet recites freedom, and lives freedom through language. (...) Liberty is novelty; novelty is liberty" in his prose titled "The Real Life and Poetry" in 1964. Secondly, he lived under the authoritarian Park Chung Hee regime; so seeking for liberty was politically suppressed. Kim Suyǒng's poetry is based on his real life, which was a matter of conscience for him. He emphasized that a poet must write her or his poem in accordance with one's conscience. Lastly, he focused on the impossibilities for reaching out to the ideal. That is why his poetic method is negation. Living in an authoritarian society, he negated the society, the Korean literary circle, and above all things, himself.

\section{The Problem of Love}

This article attempts to examine the several works of Kim Suyǒng in 1960s with a focus on negation as the poetic method in accordance with revolution. Raymond Williams suggests the basic formula of the revolution: rejecting the old leads to the transformation of the present society (Williams, 2010). From this formula, we learn "negation" falls into the rejection of the old. Yet then, in order to complete the revolution, how did he transform the old into the new by writing poetry?

That question of poēsis brings us to the other important theme of his work: love. In light of the revolution, transformation is interconnected with love. Generally, love is understood in two ways. First, love is unknown, which is related to the concept of it being a potential. Second, love is the act of embracing the other without condition. Hence, we could say that love brings novelty in a positive way.

With respect to negation, however, what is problematic love is its positivity. As mentioned earlier, Kim Suyǒng lived through the authoritarian government, so it was (almost) impossible to live up to his ideal of a better, more emancipated life. Taking this into the consideration, how did he end up considering love as a constituent of the revolution? In response, he talked about love in light of poetry. He mentioned that "the real poetry is the work of love that allows [a poet] to kill her or himself and become the other" in "The Matter of Death and Love as the Antipole Is the Essence of Poetry(<죽음과 
사랑>의 대극은 시의 본수)" in 1967. This, yet again, pose another question: if this is so, is love the absolute self-negation in spite of positivity embedded in it?

\section{The April Revolution and the Task of Poiēsis}

The April Revolution took place in 1960. It is the first turning point of his oeuvre. Kim Suyǒng felt the April Revolution was miraculous scene that the modern revolution such as French revolution finally came to occur albeit the backwardness of Korea. In turn, the revolution made him recalibrate the notion of liberty and the role poetry would play in the revolution.

So to call it, poetry accomplishes an absolute completeness, whereas revolution accomplishes a relative completeness. Then, what is the poetry conforms or aids revolution. It plays a role to either sublimate, or appear to sublimate revolution to accomplish relative completeness up to the absolute completeness. Even though poets and revolutionaries could be succored, there is no revolution whatsoever. ${ }^{1}$

This passage, an excerpt from his diary written in two months after the April Revolution, is crucial in understanding his authentic view on poetry in relation to political revolution. He thought poetry tries to sublimate the political revolution up to the absolute. It indicates that he thought literature could not be reduced to political interests.

Those who have soared aloft/ for the sake of freedom/ know/ why it is/ the skylark sees/ that makes it sing;/ they know why the smell of blood/ must mingle with freedom,/ why revolution/ is a lonely thing/ why revolution/ is bound to be a lonely thing ${ }^{2}$

\footnotetext{
${ }^{1}$ All translations are my own, unless otherwise noted.

${ }^{2}$ Suyǒng Kim., Siyoung Lee. \& Kyongnim Shin (eds.). 2001. Variations: 사 랑의 변주곡: Three Korean Poets. Tr. By B. Anthony of Taizé, and Youngmoo Kim, (Ithaca, NY: East Asia Program, Cornell University),
} 
In the second stanza of "The Blue Sky", the speaker says he can detect the smell of blood embedded in liberty. "The smell of blood" embodies the sacrifice accompanied by violence in the course of revolution. According to Raymond Williams, violence is what draws a line between evolution and revolution in terms of transformation (Williams, 2010). Put another way, it is violence that makes the old world be overthrown and the new world come into being. In the following, I will try to examine how self-directed violence (i.e. self-torture) is at work as the underlying structure of his poetry in his own response to the revolution.

\section{Infinite Betrayal as Self-directed Violence}

(1) Self-torture is regarded as being heinous from society, but I have not found the religion equivalent of the virtue of self-torture. How on earth could I live [in this society] as a snob without this kind of excuse? We do not have faith in our so-called Literature. Camus made an assertion. What did Rimbaud declare beforehand? Poetry must be absolutely modern. Therefore, we must absolutely disdain our poetry.

(2) Poet is an eternal traitor. He turns renegade every second. He betrays himself who betrays himself, who betrays himself who betrays himself who betrays himself...(...) $\mathrm{He}$ is the traitor who betrays [the other] infinitely.

As you may notice, he thought self-torture was the "modern" method to produce the new poem. As mentioned earlier, self-torture is an underlying structure of his poiēsis, so let me divide it into three parts. First, the object is him. He did not want to write a poem for a making a living, but he could not help it because he had a family. Of particular significance is that he referred to himself as a snob, and the enemy. Second, self-directed violence is the permanent selfbetrayal. The premise of the self-torture is this: if s not a poet, he cannot perform the revolution. That is a contraposition; if he instigates revolution on his everyday life, he can be a poet. Hence,

p. 61 . 
self-torture is a paradoxical method to practice the revolution driven by self-hatred. In this regard, ironically enough, the necessary and sufficient condition for it is to be a snob. However, being a snob over the course of permanent self-betrayal is a partial negation of himself. In this sense, it is close to relative completeness, not the absolute one.

Then, how did he perform "absolute completeness" by writing poetry?

\section{Language of Silence as a Martyr}

In the preceding pages, we have discovered his task in mid1960 was the absolute self-negation. However, he declared in the $6^{\text {th }}$ note that he was able to solve his task. Before developing this argument, it is worth noting that the significant of this note was proven relatively recently (Chung, 2008: Cho, 2010; Kang, 2013).

(1) But painting, (...) I think it has no future in our civilization. Neither does sculpture. What we might call bad painting-that has a future.

(2) There is no hope of expressing my vision of reality. Besides, if I did, it would be hideous something to look away from.

This is an excerpt from Giacometti's interview (Lake, 1965), which Kim Suyǒng translated into Korean at that moment. The word "hideous" is associated with the aesthetic concept, the ugliness. According to Küplen, the one of the characteristics of the ugliness is "to produce one of the unwelcome and unexpected surprise by violating our expectation as to how the world is supposed to be"(Küplen, 2015). In his article, Chung suggested that what Giacometti and Kim Suyǒng had in common was a rejection of surrealism (Chung, 2008). He said this was also the reason why Kim Suyǒng resonated with what Giacometti mentioned intensely by default. However, in a note, Kim Suyǒng suggested that the word "hideous" should be interpreted as "invisible" by dividing it into two parts: "hide" and "-eous". It is much 68 
more significant that this interpretation transforms being hideous into being invisible. This transfiguration evolved from the experience of writing the poem, "Snow".

After snow has fallen, it keeps falling. (눈이 온 뒤에도 또 내린다)

After a thought has occurred, it keeps falling. (생각하고 난 뒤에도 또 내린다.)

After a wail, will it keep falling? (응아 하고 운 뒤에도 또 내릴까?)

After a sudden thought, it keeps falling. (한꺼번에 생각하고 또 내린다)

One line passed, two lines passed, will it keep falling? (한줄 건너 두줄 건너 또 내릴까)

Will snow fall on ruins, on ruins? (폐허에 폐허에 눈이 내릴까) ${ }^{3}$

What is invisible in "Snow"? The subject of each line is not quite clear. We can assume the existence of the speaker based on the tone. In terms of sentence subject, the fourth line is crucial. As you may notice, the subjects of the sentence are not present. Given that a peculiar feature of Korean is that the subject is often dropped from a sentence, it can be regarded as being grammatically correct. However, conjunctional connective suffix "-고" makes this sentence complicated to read because the Korean speaker uses "-고" to indicate the time order between two events in two different ways. In other words, Korean allows its speaker to employ "-고" to connect two events that either happened in sequence, or at the same time. In this sense, the fourth line generates a subject-speaker mingled in snow because of its sentence structure, which is impossible in the real world. Put simply, the $4^{\text {th }}$ line contains a hint of the speaker's death.

Nevertheless, the process of death started from the third line. The third line refers to the cry of a baby, signaling the moment of birth. It's meaning is construed by the remark of Georges Bataille on the relationship between death and birth. He said that one death foretells another birth, and thus the latter takes place on the only condition that; the former had to happen beforehand (Bataille, 2009). In this sense, the cry of the baby paradoxically implies death. In this regard, the "ruins (폐허)" in the sixth line refers to death. This line is also explained by Bataille's remark on death as a sign of the violence, which converted the world into the wasteland

\footnotetext{
${ }^{3}$ Kim et al, op. cit. p. 103.
} 
(Bataille, 2009). Therefore, the death of the speaker presented in "Snow" is a kind of self-directed violence at the ultimate level. Death is portrayed the disappearance from the world, related to the "invisibility".

Hurray! Hurray! I adhere to language.

In the last part of the note, Kim Suyorng exclaimed these sentences with full joy. In order to "adhere to the language", or to vanish into the language, the death of speaker has to take place. Put otherwise, the death of speaker is equivalent to the eradication of her or his voice. Furthermore, adhering to language means ultimately becoming other. In his view, becoming the other is the act of love. $\mathrm{He}$ made a statement in "Thaw" that silence is the "only method" of the action of love. As he lived in the authoritarian regime, silence was his only truthful method to enact love through language.

\section{Conclusion}

Kim Suyǒng is a poet of liberty. He lived through a late colonial period, Korean War, the April Revolution, and Park Chung Hee's regime. He was keenly aware that Koreans had not spoken liberty as the invention of modernity in our mother tongue throughout the history. For the sake of inventing a new language, he dedicated all his poems to demonstrating the reason liberty was impossible to be spoken in Korean. In the course of writing, his authentic poetic language developed into silence, a language to dream of liberty. Still, his poetry embedded in the Korean historical wounds is breathing silently for love.

\section{Notes}

* Excerpts of this paper are taken from the fourth chapter of my Master's Thesis: Choi, Seoyoon, 2012. "A Study on Aporia of Kim Sooyoung's Poetry." Seoul: Yonsei University. I would like to thank 
the two anonymous referees for International Journal of Korean Humanities for their helpful and important comments and suggestions.

\section{References}

Bataille, Georges. 2009. Erotism. tr. by Cho, Hankyung, Seoul; Minǔmsa.

Cho, Kangsok. 2010. "A Study on the Turning Points of Kim Sooyoung's Poetics - Focusing on the 'dramatic features in poetry' and 'Alberto Giacomettian transformation.", The Korean Poetic Studies Vol. 28.

Choi, Seoyoon, 2012. A Study on Aporia of Kim Sooyoung's Poetry. Seoul: Yonsei University.

Chung, Myǒngkyo. 2008. "Kim Suyǒng and French Literature." The Korean Poetic Studies Vol. 22.

Kang, Gyesook, 2013. "Study on the importance of bilingualism and 'Alberto Giacomettian Transformation' in Kim, SooYŏng's literature.” Journal of Modern Korean Literature Vol. 27.

Kim, Suyǒng. 2003. Collected Works of Kim Suyǒng Volume 1, 2. Seoul; Minǔmsa.

Kim, Suyǒng., Lee Siyoung. \& Shin Kyongnim. (eds.).2001. Variations: 사랑의 변주곡: Three Korean Poets. Tr. by Anthony of Taizé, Brother and Kim, Youngmoo, Ithaca, NY: East Asia Program, Cornell University

Küplen, M. 2015. Beauty, Ugliness, and the Free Play of Imagination. Switzerland: Springer

Lee, Youngjun. 2015. "Sovereignty in The Silence of Language: The Political Vision of Kim Suyǒng's Poetry", Acta Koreana Vol. 18. No. 1.

William, Raymond. 2010. Keyword. tr. by Kim, Sǒngki, Seoul; Minǔmsa. 